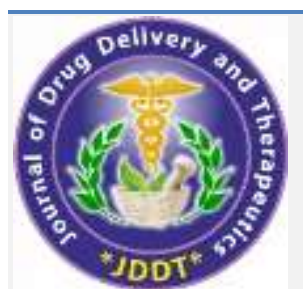

Open

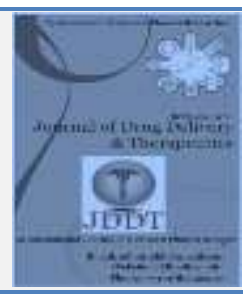

\title{
Video media versus image media in dental health education about the bass brushing technique: Which is more effective?
}

\author{
Quroti A'yun \\ Department of Dental Health, Poltekkes Kemenkes Yogyakarta, Yogyakarta, Indonesia
}

\section{Article Info:}

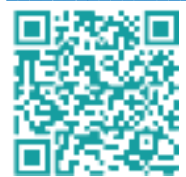

\section{Article History:}

Received 11 November 2021 Reviewed 26 December 2021 Accepted 04 January 2022

Published 15 January 2022

Cite this article as:

A'yun Q, Video media versus image media in dental health education about the bass brushing technique: Which is more effective?, Journal of Drug Delivery and Therapeutics. 2022; 12(1):36-38

DOI: http://dx.doi.org/10.22270/jddt.v12i1.5275

*Address for Correspondence:

Quroti A'yun, Department of Dental Health, Poltekkes Kemenkes Yogyakarta, Indonesia

\author{
Abstract
}

Background: Brushing teeth to maintain dental and oral health can be done by various methods. The proper brushing method is very important in achieving dental and oral hygiene. One of them is brushing teeth with the bass method. The bass method is one of the recommended brushing methods in dentistry. Objective: This study aims to determine the effect of dental health education using video media on how to brush teeth with the Bass technique on the knowledge of brushing teeth in school children. Methods: This study used a quasi-experimental design with a pretest-posttest control group design. The sample in this study was taken by purposive sampling as many as 54 children aged 9-12 years. The research was conducted at the Al Istiqomah Mosque TPA, Sumberagung Village, Moyudan District, Sleman Regency. The research instrument used a questionnaire about brushing teeth. Dental health education in the intervention group used video media brushing teeth with bass technique, while in the control group used images media. Data analysis used descriptive analysis and independent t-test to compare the difference in knowledge scores of the treatment group and the control group. Results: the mean value of knowledge in the intervention group before was $11.19 \pm 1.54$ and after was $12.11 \pm 1.33$. The mean value of knowledge before in the control group was $11.24 \pm 1.58$ and after $11.44+1.22$. The results of the knowledge dependent $t$-test in the intervention group were $\mathrm{p}=0.040$ and in the control group were $\mathrm{p}=0.326$. The results of the independent $\mathrm{t}$-test were obtained $\mathrm{p}$ $=0.038$. Conclusion: Video media is more effective in increasing tooth brushing knowledge than image media for school-age children

Keywords: Video media, image media, tooth brushing knowledge, bass technique, school age children

\section{INTRODUCTION}

Dental and oral health is a very important part of overall health. Dental and oral health in Indonesia needs to be considered because dental and oral disease is the highest disease that people complain about. Dental and oral health in Indonesia is still not a priority for most people. The oral cavity is the gateway for the entry of germs and bacteria that can interfere with the health of the teeth and mouth and other organs of a person's body. The problem of cavities is still a lot of complaints and cannot be allowed to get worse because it will affect the quality of life where they will experience pain, discomfort, disability, acute and chronic infections, eating and sleeping disorders, and have a high risk of being hospitalized, which causing high medical costs. ${ }^{1-3}$

Maintenance of dental and oral health can be done by maintaining dental and oral hygiene. Bad oral and dental hygiene can cause plaque buildup which will cause various dental and oral health problems and periodontal tissue disease. Early prevention efforts really need to be done to reduce the risk of developing dental and oral diseases. 4,5

Brushing teeth is an important routine in maintaining dental hygiene. Brushing teeth can prevent caries, tartar, and other diseases. Brushing teeth is an initial step in maintaining oral hygiene and giving a fresh feeling in the mouth.6,7 Basic Health Research in Indonesia, only $2.8 \%$ of the population brushed their teeth properly as recommended, in the morning after breakfast and at night before going to bed.
This can happen due to a less of dental health knowledge and understanding of the community about oral hygiene. ${ }^{8}$

Brushing your teeth to keep your teeth and mouth healthy can be done by various methods. The proper brushing method is very important in achieving dental and oral hygiene. One of them is brushing teeth with the bass method. Ristika's research showed that the average value of dental plaque before being given counseling on brushing teeth with the bass method was 3.094 and the average value after being given counseling on brushing teeth with the bass method was 0.916 . The bass method is one of the recommended brushing methods in dentistry. This is done by tilting the bristles at $45^{\circ}$ to the long axis of the tooth pointing apically with the tips of the bristles in the gum pocket. The toothbrush is moved by short back and forth vibrations which will cause the bristles to vibrate to clean the sulcus. For each section it is recommended 10 times. ${ }^{9-11}$

Video is a moving image accompanied by sound. Audio-visual media itself relies on the sense of hearing and the sense of sight. Videos can present information, describe processes, explain complex concepts, teach skills, shorten or extend time, and influence attitudes. Munadirah's research proves that the use of video media is more effective than the use of flipchart media in increasing oral health knowledge. ${ }^{12-14}$

\section{MATERIALS AND METHODS}

The research design used a quasi-experimental design with a pretest and posttest design with a control group. The change observed in this study was an increase in knowledge about brushing methods. The study was conducted at the Al Istiqomah 
Mosque TPA, Sumberagung Village, Moyudan District, Sleman Regency from June - September 2021. The sample was taken by purposive sampling with a total sample of 54 children consisting of 27 intervention groups and 27 control groups. Inclusion criteria for research samples: Age 9-12 years, good nutritional status of children, no systemic disorders, willing to be a research sample and parents willing to sign informed consent.

The independent variable in this study was dental health education with video and image media about the bass technique in brushing teeth, while the dependent variable was knowledge of brushing teeth. The instrument in this study for the variable knowledge of brushing teeth was measured using a questionnaire which included the notion of brushing teeth, toothbrush bristles, frequency and time of brushing teeth, how to choose a toothbrush, how to brush teeth with the bass method, and the right time to replace a toothbrush. Data analysis used paired sample t-test to analyze differences in knowledge before and after treatment and independent t-test to compare the difference in knowledge scores between the intervention group and the control group.

\section{RESULT}

Table 1. Frequency distribution of respondent characteristics

\begin{tabular}{cccc}
\hline No. & Variable & $\mathrm{N}$ & Percentage (\%) \\
\hline 1 & Age & & \\
& 9-10 years & 23 & 42.6 \\
& 11-12 years & 31 & 57.4 \\
& total & 54 & 100 \\
2 & Gender & & \\
& Male & 22 & 40,7 \\
& Female & 32 & 59,3 \\
& total & 54 & 100 \\
\hline
\end{tabular}

Table 1 shows that most of the respondents are female (59.3\%) and aged $11-12$ years (57.4\%).

Table 2. Description of tooth brushing knowledge

\begin{tabular}{lcccc}
\hline Knowledge & Min & Max & Mean & SD \\
\hline Intervention group & & & & \\
Pre-test & 7 & 13 & 11.19 & 1.54 \\
Post-test & 9 & 14 & 12.11 & 1.33 \\
Control group & & & & \\
Pre-test & 7 & 14 & 11.24 & 1.58 \\
Post-test & 8 & 14 & 11.44 & 1.22 \\
\hline
\end{tabular}

Table 2 shows that the mean pre-test knowledge of the treatment group is $11.19 \pm 1.54$ (good) and post-test is $12.11 \pm 1.58$ (good), while the control group is $11.24 \pm 1.58$ and $11.44 \pm 1.22$

Table 3. The results of the effectiveness test of tooth brushing knowledge before and after the intervention

\begin{tabular}{llll}
\hline Knowledge & Pre-test & Post-test & p-value \\
\hline Intervention group & 11.19 & 12.11 & 0.040 \\
Control group & 11.24 & 11.44 & 0.326 \\
\hline
\end{tabular}

Table 3 shows that the results of the analysis of the difference test with the paired sample t-test there are differences in knowledge before and after treatment in the intervention group $\mathrm{p}=0.040(\mathrm{p}<0.05)$ and in the control group there is no difference $\mathrm{p}=0.326(\mathrm{p}>0.05)$.
Table 4. The results of of tooth brushing knowledge in the intervention and control group

\begin{tabular}{lll}
\hline Group & $\Delta$ Mean & p-value \\
\hline Intervention & 0.92 & 0.038 \\
Control & 0.20 & \\
\hline
\end{tabular}

Table 4 shows that the results of the analysis of the different test with the independent $t$-test was $0.038(\mathrm{p}<0.05)$, it showed that there were differences in the knowledge of brushing teeth in the intervention and control groups.

\section{DISCUSION}

The results of the paired sample t-test show that there is a significant difference between the pretest and posttest knowledge in the intervention group $(\mathrm{p}<0.05)$. These results are in accordance with Yusdiana's research that there was an increase in knowledge after dental health education was carried out with animated video aids. Knowledge improvement can be done by conducting counseling, in which extension activities are a two-way communication process between communicators and communicants in an interaction. Dental and oral health counseling conducted is a learning process aimed at students in order to increase the degree of dental and oral health to the maximum. The selection of the right method in the process of delivering extension materials greatly helps the achievement of efforts to increase knowledge and change the behavior of the target. Online dental health education is the most effective and efficient method in the midst of the outbreak of the Covid-19 virus. In addition, online counseling activities are also a form of support for the government's hard efforts to immediately end the Covid-19 pandemic which has been going on for quite a while. ${ }^{15-17}$

Video brushing teeth with the bass technique is a learning tool to reduce the risk of caries by correcting bad behavior. There are three key elements of trust in the Health Belief Model, which is used to assess whether a person will follow the recommendations of a disease prevention behavior or not. Among these are threats, exit expectations, and efficacy expectations. The development of children is divided into early childhood (0-5 years), middle (6-11 years) and late or adolescent (12-18 years). Each phase is always marked by changes, namely: biological changes, namely physical changes in the individual's body; cognitive changes, namely changes in individual intelligence and socio-emotional changes, namely changes in relationships between individuals, with other people, emotions, personality and social contacts. Children who start elementary school, will start a new chapter in their lives that will change their attitudes and behavior. ${ }^{18-20}$

Biological changes in children begin with learning to master motor skills. ${ }^{19}$ The development of physical abilities in children looks at the strength of coordination, flexibility and balance, fluency, ability to control and variety of movements. Various basic movements and their variations that can be pretested will experience an increase in quality or experience refinement. Cognitive development in childhood begins with weighing, describing, connecting, and finally making decisions. In normal growth, the mind develops gradually until the child reaches the age of 12 years. His memory becomes very strong and has a high memorization ability. During the learning period, children will increase their knowledge and abilities until they reach good habits. This time children are able to understand the process of dental caries, its consequences and how to prevent it. ${ }^{21-23}$

Video is one of the teaching media where recorded video material is presented with computer control to the audience who not only hears and sees video and sound, but also gives an 
active response. The benefits of using videos include videos that can accurately describe a process that can be watched repeatedly if deemed necessary, in addition to encouraging and increasing motivation, videos instill attitudes and other affective aspects, videos that contain positive values can invite thought and discussion. in groups. Video is also a delivery of information or health messages. ${ }^{24,25}$

The result of the analysis of the different test with the independent $t$-test was $0.038(\mathrm{p}<0.05)$, this indicates that there is a difference in the knowledge of brushing teeth in the intervention and control groups. This means that dental health education with video media is more effective in increasing knowledge of brushing teeth than image media. The results of this study are in accordance with the research Kapti et al. which shows that audio visual media as health education media are effectively used to provide increased knowledge and change attitudes for the better. The increase in knowledge is due to the willingness in oneself to know how to brush teeth properly and correctly by paying attention to the intervention given. Providing information with video media on how to brush teeth with the bass method is interesting and can make it easier for respondents to accept the information provided. This is in accordance with the theory that the retention process (absorption and memory) of subject matter can be significantly increased if the learning process is through the senses of hearing and sight. 26,27

\section{CONCLUSION}

Based on the results of the study, it can be concluded that there is video media is more effective in increasing tooth brushing knowledge than image media for school-age children

Acknowledgements: This study was done by selffunding from the authors. The authors thank all participants and research assistants.

Conflict of Interest: The authors declare that they have no conflict interests.

Ethical Clearance: The study was conducted after obtaining approval from the Ethics Committee of the Health Polytechnic of the Ministry of Health Yogyakarta No. eKEPK/POLKESYO/0530/VI/2021

\section{REFERENCES}

1. Ngatemi, Purnama T. Dental Health Handbook as Parents Monitoring in the Formation of Independence for Brushing Teeth in Early Childhood. Indian J Public Health Res Dev. 2020; 11(1) https://doi.org/10.37506/v11/i1/2020/ijphrd/193920

2. Kitamoto S, Nagao-Kitamoto H, Hein R, Schmidt TM, Kamada N. The bacterial connection between the oral cavity and the gut diseases. Dent Res. 2020; 99(9):1021-9. https://doi.org/10.1177/0022034520924633

3. Kemenkes RI. Permenkes No 89 tahun 2015 tentang Upaya Kesehatan Gigi dan Mulut. Jakarta: Kementerian Kesehatan Republik Indonesia; 2015.

4. Ngatemi TP. Counseling with Tooth Brushing Demonstration Method as an Effort to Improve Tooth Brushing Skills and the Status of Dental and Oral Hygiene in Early Childhood at School. Med Leg Update. 2021; 21(1):684-7.

5. Adilah BH, Wardani R, Zubaedah C. Differences in oral hygiene status of Salafiyah Al-Majidiyah Islamic Boarding School students before and after oral health counselling. J Kedokt Gigi Univ Padjadjaran. 2018; 30(2):76-84. https://doi.org/10.24198/jkg.v30i3.18501
6. Purnama T, Ngatemi N, Sofian R, Kasihani NN, RE PR, Nurbayani S. Model 5 Days Gosgi sebagai upaya pembentukan kemandirian menggosok gigi anak usia dini di sekolah. Qual J Kesehatan. 2020; 14(1):19-24. https://doi.org/10.36082/qjk.v14i1.96

7. Naseem S, Fatima SH, Ghazanfar H, Haq S, Khan NA, Mehmood M, et al. Oral hygiene practices and teeth cleaning techniques among medical students. Cureus. 2017; 9(7). https://doi.org/10.7759/cureus.1487

8. Kemenkes RI. Hasil utama riskesdas 2018. Jakarta Kemenkes RI. 2018;

9. Ristika E. Perbedaan Efektivitas Menyikat Gigi Antara Metode Bass Dan Metode Roll Terhadap Plak Gigi Di SDIT Muhammadiyah Al-Kautsar Sukoharjo. Universitas Muhammadiyah Surakarta; 2014.

10. Ilyas M, Ashraf S, Jamil H. Tooth brushing techniques. Prof Med J. 2018 ; 25(01):135-9. https://doi.org/10.29309/TPMJ/18.4429

11. Sondang P, Hamada T. Menuju gigi dan mulut sehat. Medan USU Press pp. 2008;4-15.

12. Winarto W, Syahid A, Saguni F. Effectiveness the Use of Audio Visual Media in Teaching Islamic Religious Education. Int J Contemp Islam Educ. 2020; 2(1):81-107. https://doi.org/10.24239/ijcied.Vol2.Iss1.14

13. Kantohe ZR, Wowor VNS, Gunawan PN. Perbandingan efektivitas pendidikan kesehatan gigi menggunakan media video dan flip chart terhadap peningkatan pengetahuan kesehatan gigi dan mulut anak. eGiGi. 2016; 4(2). https://doi.org/10.35790/eg.4.2.2016.13490

14. Munadirah. Perbandingan efektivitas media video dan flip chart terhadap peningkatan pengetahuan kesehatan gigi dan mulut murid kelas IV dan V di SDN No 38 Boro Kec. Rumbia Kab. Jeneponto. Media Kesehat gigi. 2017; 16(38):5-10.

15. Yusdiana Y, Restuastuti T. Peningkatan pengetahuan kesehatan gigi dan mulut melalui penyuluhan menggunakan video animasi secara online pada siswi MTS Muhammadiyah Penyasawan Kabupaten Kampar. minda baharu. 2020; 4(2):52-61. https://doi.org/10.33373/jmb.v4i2.2804

16. Rofiki I, Famuji SRR. Kegiatan Penyuluhan dan Pemeriksaan Kesehatan untuk Membiasakan PHBS bagi Warga Desa Kemantren. Din J Pengabdi $\begin{array}{lll}\text { Kpd } & \text { Masy. } & \text { 2020; }\end{array}$ https://doi.org/10.31849/dinamisia.v4i4.3992

17. Pudentiana Rr RE, Subandini SL. Pendidikan kesehatan gigi. EGC. Jakarta: 2019.

18. Kumar PDM, Mohandoss AA, Walls T, Rooban T, Vernon LT. Using smartphone video "selfies" to monitor change in toothbrushing behavior after a brief intervention: A pilot study. Indian J Dent Res Off Publ Indian Soc Dent Res. 2016; 27(3):268. https://doi.org/10.4103/09709290.186241

19. Abraham C, Sheeran P. The health belief model. Predict Heal Behav Res Pract with Soc Cogn Model. 2015;2:30-55.

20. Snorrason I, Ricketts EJ, Stein AT, Thamrin H, Lee SJ, Goldberg H, et al. Sex differences in age at onset and presentation of trichotillomania and trichobezoar: a 120-year systematic review of cases. Child Psychiatry Hum Dev. 2021; 1-7. https://doi.org/10.1007/s10578-020-01117-y

21. Holfelder B, Schott N. Relationship of fundamental movement skills and physical activity in children and adolescents: A systematic review. $\begin{array}{llll}\text { Psychol Sport } & \text { Exerc. } & \text { 2014; } & \text { 15(4):382-91. }\end{array}$ https://doi.org/10.1016/j.psychsport.2014.03.005

22. Sujiono YN, Zainal OR, Rosmala R, Tampiomas EL. Hakikat Pengembangan Kognitif. Metod Pengemb Kogn. 2013; 1-35.

23. Nugraheni H, Sadimin S, Sukini S. Determinan Perilaku Pencegahan Karies Gigi Siswa Sekolah Dasar di Kota Semarang. J Kesehat Gigi. 2019; 6(1):2634. https://doi.org/10.31983/jkg.v6i1.4404

24. Arsyad A. Media pembelajaran. Jakarta: PT Raja grafindo persada; 2011

25. Notoatmodjo S. Promosi Kesehatan Teori dan Aplikasi, RinekaCipta Jakarta; 2010.

26. Kapti RE, Rustina Y, Widyatuti W. Efektifitas audiovisual sebagai media penyuluhan kesehatan terhadap peningkatan pengetahuan dan sikap ibu dalam tatalaksana balita dengan diare di dua rumah sakit kota Malang. J Ilmu Keperawatan J Nurs Sci. 2013; 1(1):53-60.

27. Daryanto. Media pembelajaran peranannya sangat penting dalam mencapai tujuan pembelajaran. Gava Media. 2013; 